Progress in Development Studies 13, 4 (2013) pp. 323-338

\title{
Improving the quality of development research: What could archiving qualitative data for reanalysis and revisiting research sites contribute?
}

\author{
Laura Camfield
}

School of International Development, University of East Anglia

\section{Richard Palmer-Jones}

School of International Development, University of East Anglia

\begin{abstract}
As the emphasis on evidence-based policymaking in international development increases, so too should the attention paid to the quality of the research on which this evidence is based. One way to encourage this is by archiving research data to enable reanalysis, but this requirement is often ignored or resisted by development researchers. Similarly, ambivalent feelings are expressed about revisits to former research sites to conduct further research by original and other researchers. In this article, we outline why and how researchers archive and reanalyze qualitative data and revisit research sites, and discuss the potential benefits and challenges of these practices for development research.
\end{abstract}

Key words: Secondary analysis, revisits, archiving, qualitative, data quality

\section{Introduction}

A question frequently asked of qualitative researchers working in development is, "how can you demonstrate that your findings are accurate, representative, free from unacknowledged bias, soundly interpreted, etc.?' Answers to these questions are philosophical, methodological and ethical. They are philosophical because they reflect different ontologies and epistemologies operating within development research (that is, understandings of what it is we are trying to understand and how we know what we know). They are methodological because they have important implications for research design and conduct. They are also ethical because they relate to moral issues in conducting and reporting research, including obligations to meet professional standards and make efficient use of public resources (Bishop, 
2009; Hammersley and Trianou, 2012). This special issue addresses methodological dimensions of research ethics and in this article, we argue that emerging practices such as reanalysis of qualitative data and revisits to research sites offer the same opportunity for qualitative researchers to confirm and extend their analyses as replication does for quantitative researchers (see 'Replication of Quantitative Work in Development Studies: Experiences and Suggestions' by Duvendack and Palmer-Jones in this issue).

One reason for the growing interest in reanalysis and revisits is the challenge of assessing the quality of qualitative research merely on the basis of outputs, as anyone conducting a systematic review will have realized (for example, were conclusions based on a single, striking interview, or a systematic analysis of the whole sample?) Qualitative research within development faces particular challenges as it is often conducted by researchers either not socialized in a discipline such as anthropology or sociology, which has clear guidelines for fieldwork and note taking, or so resource constrained as to be unable to follow them. Data production and analysis are often separated (we return to this point when we discuss reanalysis), for example, through the use of research assistants and translators. For this reason, the distinction between primary and secondary analysis, which is prominent in debates over reanalysis (Bishop, 2009; Moore, 2007; Silva, 2007), may be less visible in development as, in large-scale research projects, analysis often happens without knowledge of either the context in which the data were produced or the research process.

In this article, we discuss two types of activity: reanalysis and reuse of data; and revisits to field sites (see articles by Irwin and Crow in this issue). While these terms can be used in different ways, and the boundaries are blurred, we take them to mean the following: reanalysis is when original materials are re-examined (reanalyzed) often by new authors, but sometimes by the original author, with or without returning to the original research site. The new authors may draw not only on the archived materials from the original research but also on other contemporary and more recent materials, and may use different theoretical approaches than the original (Table 1). Reuse is where original materials are used for purposes other than those in the original study (Table 1).

Table 1 Examples of secondary analysis

\begin{tabular}{|c|c|c|}
\hline Original authors & Topic of reanalysis & Reanalysis authors \\
\hline $\begin{array}{l}\text { Blaxter and Patterson (1982); } \\
\text { Thompson (1975) }\end{array}$ & $\begin{array}{l}\text { Convenience foods and family eating } \\
\text { practices }\end{array}$ & Bishop (2007) \\
\hline Cohen and Taylor (1972) & Prisoners' experience of confinement & Fielding and Fielding (2000) \\
\hline $\begin{array}{l}\text { Townsend and Marsden (1960s) } \\
\text { and the authors' study in 2000s }\end{array}$ & $\begin{array}{l}\text { Feasibility study of potential for } \\
\text { historical comparative analysis of family } \\
\text { and parenting across four decades }\end{array}$ & Gilles and Edwards (2011) \\
\hline Bott (London, 1951-54) & Family and social networks & Savage $^{a}(2005 a, 2008)$ \\
\hline $\begin{array}{l}\text { Goldthorpe and Lockwood } \\
\text { (Cambridge, Luton, 1962-63) }\end{array}$ & $\begin{array}{l}\text { Affluent worker thesis (tested using } \\
\text { different understandings of class) }\end{array}$ & Savage (2005b) \\
\hline
\end{tabular}

Source: Authors' own analyses.

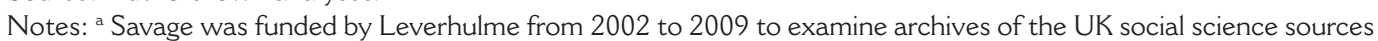
1950-70 and Mass Observation 1937-55 (Savage, 2007 - change, continuity and individualization in relation to family life; class identities). He also looked at studies by Jackson and Marsden, Working class community in Huddersfield (1961-66), Pahl, Hertfordshire studies, Managers and their Wives (1961-68), and Brown, Tyneside shipbuilding workers $(1968-70)$.

Progress in Development Studies 13, 4 (2013) pp. 323-338 
Neither is particularly common in development research, although within largescale research projects, qualitative data are frequently reused to answer a research question that was not envisaged when the data were originally collected. Revisits are when original authors, their students or other researchers return to a former research site to see what has happened or to explore new issues or ideas (see, for example, Breman, 1985, 2007 and Table 2). As with replication in quantitative research, these practices serve a number of functions: increasing understanding of the original research and its limitations; teaching research practices; exploring topics present in the data but not analyzed originally; and making better use of the public resources invested in their production, including respondents' time (Crow and Edwards, 2012).

Nonetheless, while reanalysis and revisits have elements of replication (Burawoy, 2003), they are not equivalent. With replication,

Table 2 Examples of revisits

\begin{tabular}{|c|c|c|c|}
\hline Original authors & Topic & Restudy authors & Focus of restudy \\
\hline Redfield (1930) & $\begin{array}{l}\text { Tepoztlán, } \\
\text { Mexican village }\end{array}$ & Lewis (1951) & $\begin{array}{l}\text { Challenged 'folk-urban' } \\
\text { continuum and emphasis on } \\
\text { cooperation }\end{array}$ \\
\hline Kushner et al. (1958) & $\begin{array}{l}\text { Viriatino, } \\
\text { Russian village }\end{array}$ & Alym & $\begin{array}{l}\text { Used work of past } \\
\text { ethnographers to explore } \\
\text { Soviet-era politics of } \\
\text { knowledge }\end{array}$ \\
\hline $\begin{array}{l}\text { Bryson and } \\
\text { Winter (1972) }\end{array}$ & $\begin{array}{l}\text { 'Newtown', Melbourne } \\
\text { suburb, Australia }\end{array}$ & $\begin{array}{l}\text { Bryson and } \\
\text { Winter (1999) }\end{array}$ & $\begin{array}{l}\text { Effects of economic } \\
\text { restructuring between the } \\
1960 \text { s and the 1990s }\end{array}$ \\
\hline $\begin{array}{l}\text { Sheldon } \\
\text { (Wolverhampton,1948), } \\
\text { Young and Willmott } \\
\text { (Bethnal Green, 1957, } \\
\text { Woodford, 1960) }\end{array}$ & $\begin{array}{l}\text { Community change and } \\
\text { older people, the UK }\end{array}$ & $\begin{array}{l}\text { Phillipson et al. } \\
\text { (1998) }\end{array}$ & Feasibility of replication \\
\hline $\begin{array}{l}\text { Rosser and Harris } \\
\text { (Swansea, 1965) }\end{array}$ & $\begin{array}{l}\text { Changes in family } \\
\text { structures and support } \\
\text { networks over time, } \\
\text { the UK }\end{array}$ & $\begin{array}{l}\text { Charles et al. } \\
(2008)\end{array}$ & $\begin{array}{l}\text { Continued social vitality } \\
\text { of extended families in } \\
\text { heterogeneous urban settings }\end{array}$ \\
\hline Townsend (1962) & $\begin{array}{l}\text { Residential care homes } \\
\text { for older people, the UK }\end{array}$ & $\begin{array}{l}\text { Johnson et al. } \\
\text { (2010) }\end{array}$ & $\begin{array}{l}\text { Tracing original homes and } \\
\text { seeing how they have changed }\end{array}$ \\
\hline Lynd and Lynd (1937) & $\begin{array}{l}\text { Muncie or 'Middletown', } \\
\text { the US }\end{array}$ & $\begin{array}{l}\text { For example, } \\
\text { Caplow et al. (1982) }\end{array}$ & $\begin{array}{l}\text { Changes in American family } \\
\text { values }\end{array}$ \\
\hline Dennis et al. (1956) & $\begin{array}{l}\text { A mining town, Ashton, } \\
\text { Yorkshire, the UK }\end{array}$ & $\begin{array}{l}\text { Warwick and } \\
\text { Littlejohn (1992) }\end{array}$ & $\begin{array}{l}\text { Effects of changes in the } \\
\text { labour market }\end{array}$ \\
\hline $\begin{array}{l}\text { Norbert Elias and } \\
\text { team - unpublished due } \\
\text { to disputes over research } \\
\text { design, methods and } \\
\text { individual researchers' } \\
\text { right to publish }\end{array}$ & $\begin{array}{l}\text { Young people's early } \\
\text { work experiences in the } \\
1960 \text { s (the UK) - traced } \\
40 \text { years later and } \\
\text { reinterviewed about } \\
\text { their working lives as } \\
\text { they prepare to retire }\end{array}$ & $\begin{array}{l}\text { O'Connor and } \\
\text { Goodwin }(2010)\end{array}$ & $\begin{array}{l}\text { Change in individuals over } \\
\text { time }\end{array}$ \\
\hline
\end{tabular}

Source: Authors' own analyses. 
issues are often framed in an abstract and timeless way - would different researchers using the same materials get the same results? In qualitative research, not only is the research object beyond our control, but 'we have to work with an instrument that cannot be calibrated and whose working is only partially known: human individuals with their ears and eyes' (Kloos, 1997: 421). For this reason, Descola (2005: 69) describes 're'visiting as impossible because knowledge produced through fieldwork 'derives from an intersubjective exchange the conditions for which are never identical' and is jointly produced and owned with the subject (Parry and Mauthner, 2004). The implications of this are that a revisit can never repeat or 'replicate' a previous event, but is always a new visit, albeit traces of the previous research remain (for example, the construction of a field site through the process of research; Kloos, 1997). This is even true when the same researcher revisits as people's sensitivity to different issues and the way people respond to them is influenced by their life stage (for example, new mother) as well as their 'intellectual autobiography' (Mauthner et al., 1998; Stanley, 1990). The same concerns over the feasibility of replication apply to reanalysis as the data do not exist independently of the analytical frame. Some authors suggest that the requirement to archive data inadvertently constructs all data production as 'empiricist research designed to produce objective, cumulative knowledge' (Cheshire et al., 2009; Travers, 2009: 286).

Ethical concerns relating to confidentiality and consent (the main reason given for not archiving data, according to Bishop, 2009) are important considerations, as are the resources required to prepare qualitative materials for archiving or revisits. However, we suspect that these concerns relate to the protection of researchers and their reputations rather than subjects (Broom et al., 2009). We argue that the fluid and subjective nature of research encounters does not obviate the need for qualitative researchers to support their interpretations, for example, by showing how the data support the arguments drawn from them and providing evidence of proper and rigorous conduct of the research (Hammersley and Trianou, 2012: chapter 2). Otherwise, their claim to authority is 'no different from saying "trust me, I was there"' (Bishop, 2009: 266).

In the remainder of this article, we review the growing practice of secondary qualitative data analysis and revisits to field sites, to assess their potential contribution to research and analysis within international development. We could find few published examples of purely secondary qualitative data analysis using data from developing countries, presumably due to lack of data, so we have illustrated its potential with examples from history and sociology. These show how the longitudinal dimension of revisits and reanalysis can capture the intersection of biographical, historical and generational change over time, which is an important consideration for a field such as development studies that struggles to reconcile structure and agency and take history into account (Lewis, 2009).

\section{Archiving and reanalysis of qualitative data}

In this section, we look at secondary analysis of qualitative data, which is both a new area for development research and a perennial problem for studies where research design and analysis are separated from data collection (the challenges this presents are described in Mauthner and Doucet, 2008 and Mauthner and Edwards, 2010). Qualitative data present particular challenges for interpretation relating to sample size and composition, tensions between emic and etic understandings, limitations to observation due to barriers between front and backstage behaviour, quality of fieldnotes, memory and so on. The challenges are arguably doubled when engaging in secondary analysis of qualitative data (Mauthner and Parry, 2009; Parry and Mauthner, 2004), but this is nonetheless increasingly popular in the UK, which, some researchers argue, is due in part to increasing

Progress in Development Studies 13, 4 (2013) pp. 323-338 
regulation of fieldwork by university ethics committees (Hammersley, 2009). Archiving of qualitative data is seen as an important way in which qualitative researchers can meet broader ethical obligations:

Regarding the scholarly community, there is a clear duty of openness and transparency, and this is increasingly being seen to include data, along with methodology and findings... regarding the public interest and wider society, there is a duty to benefit society, directly or by increasing knowledge and understanding. (Bishop, 2009: 259)

Secondary analysis of qualitative data in the UK has been promoted and facilitated by the development of the Qualidata archive in 1994 - its quantitative equivalent started in 1969 - and the archiving of classic UK studies such as Thompson's (1975) The Edwardians (initiatives in other countries are described in note 3 and Mauthner and Parry, 2009). There have been numerous journal special issues ${ }^{1}$ indicating a growing community of practitioners. Perhaps more importantly, there is an increasing expectation among research funders such as the UK Economic and Social Research Council (ESRC) that grant holders will deposit their data ${ }^{2}$ and funding for secondary analysis. This provides an opportunity to both 'validate' original studies (although this is problematic; see Savage, 2007) and stimulate new ones.

The lack of international qualitative data for analysis ${ }^{3}$ - Qualidata holds only a couple of non-European studies - suggests that this is a peripheral area for development researchers, although it is also a requirement for projects funded under the joint Department of International Development (DFID) ESRC scheme for research on international development (2005 onwards). However, the methodological debates around the viability of secondary analysis of qualitative data (as with revisits) highlight the importance of the 'cultural habitus' (embodied knowledge) acquired through participating in fieldwork. Without it, researchers can succumb to what Mauthner et al. (1998: 743) call 'naive realism' where transcripts or extracts of multiple transcripts coded in a qualitative data analysis computer programme become the data, divorced from both fieldworkers and respondents. Elsewhere, we have argued that in development research, the limited role of those closest to the data in the analysis is often overlooked as there is little information about how researchers conduct fieldwork and analysis, either individually or as a team, and little guidance from funding agencies or disciplinary organizations on appropriate reporting of practice (Camfield, 2014; see also Mauthner and Edwards, 2010, on the repositioning of principal investigators as research managers in the UK universities). For this reason, the further mediation of qualitative data caused by interpretation, transcription and translation is also overlooked. Indeed, Temple et al. (2006) argue that the double removal of the analyst from the data by not participating in its production and not understanding the language in which it was produced ${ }^{4}$ effectively makes it 'tertiary' rather than 'secondary' data analysis.

Even though most development research is essentially secondary analysis (the analysis of data produced by others), there is a great reluctance to deposit qualitative data (and in some cases, quantitative data) for others' use (Bishop, 2009). This may indicate a different relationship to data, for example, seeing it as support for recommendations that may have been drafted before the fieldwork started, rather than as a public good that could be productively reanalyzed by future researchers. More cynically, it might indicate a reluctance to expose fragile research practices to public scrutiny (we return to this point in the conclusion). In the remainder of the section, we present examples of secondary analysis of qualitative research material (Table 1) and discuss the advantages and limitations of secondary analysis (summarized in Table 3).

The examples we provide in Table 1 are drawn from experiences in the Global North to illustrate the potential of reanalysis in development contexts. They present a range 
Table 3 Benefits and limitations of secondary analysis (drawing on the Timescapes working paper series)

\begin{tabular}{ll}
\hline Benefits & Limitations \\
\hline Reveal new methodological insights by reflecting & Interpretation of data that the researcher was \\
on previously conducted research (for example, & not directly involved in producing, albeit these \\
$\begin{array}{l}\text { Mauthner et al., } 1998 \text { and Savage, 2005b). Show } \\
\text { challenges are evident in current development }\end{array}$ & $\begin{array}{l}\text { research practices. }\end{array}$
\end{tabular}
writing shape the conclusions drawn from a dataset.

Little difference between primary and secondary analysis (Bishop, 2009; Hammersley, 1997) as 'even typically involve subjectivities and epistemologies primary data are contingent, partial and incomplete' (Bishop, 2007: 1178) and participants rarely have a direct role in analysis.

Increases use of data - as a public good or community good within a particular discipline and can enhance the credibility of social science by providing access to a larger body of data (Cheshire et al., 2009).

Respects the time and knowledge of informants by making their data widely available, even if it is initially embargoed (Cheshire et al., 2009), and reduces respondent burden.

Enables assessment of the quality of the studies claims are based on: 'Once someone makes public claims they have a moral obligation themselves to ensure that the basis for those claims can be scrutinized at some point' (Broom et al., 2009: 1175).

Assess the credibility of new research and/or the generalizability of small studies by looking at established data. Supplement one's own data to enable generalization to larger samples or test one's interpretation.

Discomfort with archiving among some social scientists not universal - for historians, only way that their discipline can move forward. Differences in perceptions may relate to the extent to which researchers rely on interviews rather than other forms of data collection and the 'special relationship' between researcher and research participant that is associated with this method.
Data produced using interpretive approaches that do not lend themselves to data archiving (for example, understanding of data as generated or co-produced with the respondent rather than collected) (Parry and Mauthner, 2004). Concept of the archive as a 'databank' suggests that data are pre-existing rather than co-created and value driven (Hammersley, 1997; Moore, 2007).

Archiving requires substantial changes in research practice and levels of funding and much of the burden falls on early career researchers, as well as researchers in the countries where fieldwork took place. Difficult to archive sufficient metadata to embed secondary analysts in the context of data generation and fears that this would threaten the reputation of the original researcher/s (Broom et al., 2009).

Can data be separated from theoretical positioning and interests of individual researcher/s and reanalyzed by a differently positioned researcher/s? (cf. meta-analysis, Hammersley, 1997: 139).

Requires change in attitudes to anonymity/ confidentiality, that is, understanding obligations to provide data as well as obligations to protect subjects (Bishop, 2009).

Ownership - for some qualitative researchers, data are seen as produced by the researcher in the same way as outputs and are equally subject to intellectual property considerations. 


\begin{tabular}{l}
\hline Benefits \\
\hline Providations \\
concerns (for example, Bishop, 2007; Bornat, 2005; \\
and Gillies and Edwards, 2005). Generate new \\
findings by analyzing 'old' data in a new context or \\
through a new theoretical lens.
\end{tabular}

Source: Authors' synthesis of sources cited in the table.

of approaches from using data collected for a broad-ranging study for a specific purpose (Bishop, 2007), in this case reflecting a contemporary preoccupation (the relationship between family meals and family breakdown), to reanalyzing the same dataset through a different theoretical lens (Savage, 2005a, 2005b, 2008). Three of the five analyses by Fielding and Fielding (2000) and Savage (2005a, 2005b, 2008) could be characterized as replicative in that they look at the themes that were not taken up, the information that was omitted from the picture and the effects on the analysis of changing the conceptualization of a key dimension. For example, Goldthorpe et al.'s study (1968) aimed to test the 'affluent worker' hypothesis by taking highly paid car assembly workers at the Vauxhall factory in Luton as a 'critical case' to investigate whether everyone was becoming middle class. Goldthorpe and Lockwood concluded that this wasn't the case, albeit on the basis of a small quantitative sample and (Savage argues) inadequate engagement with the rich qualitative material. Savage (2005a: 39) suggests that the conclusion arose because they had fitted their data into a particular typology which closed off alternative interpretations. Bishop (2007) and Gillies and Edwards (2011) are less inclined to problematize the data, although equally aware of the influence of social and research norms on what was recorded and presented. For example, Gillies and Edwards (2011: 23) describe how in addition to accent, 'mothers' physical attractiveness (or lack of it) is commented on... [and] perceived intelligence and character was also subject to evaluation'. Not only is this a refreshing contrast to the airbrushed picture of respondents presented by some community researchers (see Crow in Article 1 in this volume), it also provides valuable insights into contemporary mores.

Despite the potential of these analyses, some authors maintain they offer only methodological insights and not substantive or theoretical advances (Mauthner et al., 1998) and that the ethical and epistemological problems are too difficult to overcome (Hammersley, 2010; Mauthner and Parry, 2009; Parry and Mauthner, 2004). Others suggest, pragmatically, that the value of secondary analysis depends on the study's objectives and research questions (Bishop, 2007; Irwin and Winterton, 2011) and that rather than debate this in the abstract, we need accounts of how to interpret others' qualitative materials (Geiger et al. , 2010; Savage, 2005a). As with replicating studies rather than collecting new data (Duvendack and Palmer-Jones, this issue), secondary analysis is not a short cut and depends on having 'a detailed understanding of the research project(s)...the structure of project data...the content of data, and its internal diversity', and how this might affect the ability of the data to speak to particular research questions (Irwin and Winterton, 2012: 1). This is, of course, harder to do without the detailed insider or tacit information of the original researchers. It also requires analysts to place data in their historical and theoretical context, and recognize that context is not separable from but constitutive of the data (Mauthner and Parry, 2009). In the remainder of this section, we briefly review the potential of secondary analysis as

Progress in Development Studies 13, 4 (2013) pp. 323-338 
research audit, the important of embodied and contextual knowledge and concerns relating to confidentiality and consent.

1 Secondary analysis as 'research audit' Bishop (2007) suggests that preparing to deposit data could act as a form of 'research auditing', which Lincoln and Guba (1985: 318-19) see as one of the principal techniques for establishing the 'confirmability' (objectivity) of qualitative findings. Bishop acknowledges that the audit analogy is inappropriate because it is hard to judge the quality of the data and interpretation, or to make the processes of research fully explicit, even by using established and time-consuming forms of ethnographic reporting. Nonetheless, the requirement to archive data is often viewed as a form of audit: 'yet another step [towards] rendering social research more publicly accountable, cost-effective and regulated' (Cheshire et al., 2009: 249). This perception may also affect the conduct of research, with both positive and negative outcomes (for example, a reduction in the candour of fieldnotes in the anticipation of scrutiny). A final concern is whether researchers/research users will be able to make use of archived data, given the shortage of time even to read reports, let alone verify them. Nonetheless, even though few readers of the American Economic Review download the datasets that accompany published papers and reanalyze them, the knowledge that it is possible to do this increases the confidence placed in the authors' conclusions.

\section{Does direct involvement in data production matter?}

One of the key questions in relation to secondary analysis, and much data production by development researchers, is whether direct involvement offers unique insights that can never be recaptured by third parties. Mauthner et al. (1998) state unequivocally that this is the case, due to the personal nature of qualitative data production. However, Mason (2007), Walters (2009), and Arvidson (this issue) argue that having some distance from the data and emotional detachment can be analytically helpful (for example, in moving beyond description to relate the data to theories and other evidence). As Irwin and Winterton (2011: 8) explain,

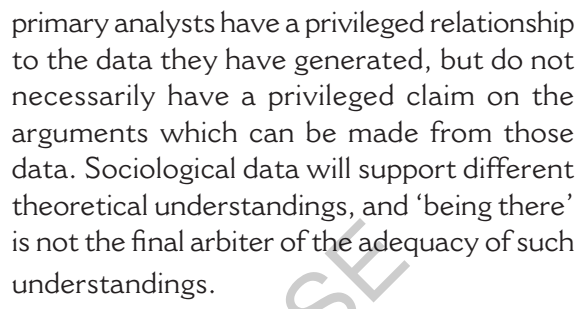

Secondary researchers may even produce more convincing accounts due to access to wider contextual data; greater resources, including time; the 'wisdom of hindsight'; and more sophisticated theoretical frameworks and methods of analysis (Walters, 2009).

\section{Fit and context}

Many of the problems attributed to secondary analysis such as 'fit', where data do not enable the researcher to answer their research questions, and context, where relevant contextual knowledge is absent, are common to all forms of research (Bishop, 2009; Moore, 2006). Hammersley (2010: 3.1) perceives a continuum of fit, ranging from data collected by a researcher to answer a specific question to purely secondary analysis, recognizing that much research falls somewhere in between. Nonetheless, he acknowledges that primary researchers may have a better sense of what inferences can and cannot be drawn from the data. Different types of research data also present different problems, for example, ethnographic fieldnotes are less amenable to secondary analysis ${ }^{5}$ than semi-structured interviews or data produced by respondentled methods such as diaries or visual materials. The predominance of interview and focus group data in development research, and its underpinning by a stance that is closer to postpositivism or critical realism than constructivism or interpretivism (that is, reality exists,

Progress in Development Studies 13, 4 (2013) pp. 323-338 
albeit that it can only be known imperfectly and probabilistically), is likely to encourage the growth of reanalysis.

In relation to the context of data production, Irwin and Winterton (2012) note how small changes in the wording and timing of biographical questions used across the Timescapes datasets - for example, whether they asked about turning points, a turning point or turning points and significant events orientate people differently. ${ }^{6}$ This example shows how "context is not about filling "gaps" in the data, but rather illuminating the very particular perspectives knowledge was (and is) created from' (Gillies and Edwards, 2005: $6)$, for example, the interests and approaches of different members of the research team. Context also includes the effects of the original data analysis as "significant "traces" of the analysis are left on the material - or "texts" to be re-analysed - and what they originally set out to do remains a part of the new context' (Silva, 2007: 6.1). Providing context for analysis is not, therefore, just about supplying as much information as possible, especially given that contextual information is data too (Parry and Mauthner, 2004). It also involves reflexivity on the part of the original researcher as it requires 'a well developed conceptual understanding of how relevant contexts hold salience for the phenomena under examination' (Irwin and Winterton, 2011: 15).

4 Confidentiality, anonymity and ownership The process of archiving qualitative data, described in Van den Eynden et al. (2011), also sharpens our attention to concerns central to research ethics, such as confidentiality, respondent and researcher anonymity and respondent consent (Parry and Mauthner, 2004). For example, since construction of qualitative data is a joint endeavour between respondent and researcher, should both parties retain authorship/ownership rights over the data to avoid its use for purposes that the respondent would not have agreed to? (See also the article by Crow in this issue.) Primary researchers who archive their data cannot easily follow the British Sociological Association's (2002) guideline that they need to discuss with research participants uses to which the data might be put as they cannot anticipate all the possible uses and their potential implications. The level of detail in datasets that combine qualitative and quantitative data and/or extend over time make it easy to identify individuals. However, removal or falsification of identifying characteristics (for example, changing the age or gender of respondents at random), or archiving incomplete data (for example, omitting sensitive cases), might compromise data quality, especially if the missing elements are likely to be used in analysis (Parry and Mauthner, 2004: 144). ${ }^{7}$ Complete anonymity may not be what respondents want (Kuula n.d., in Bishop, 2009) and arguably, 'safeguarding people's stories via an archive and allowing others to access them, albeit under restricted conditions, is a more appropriate way of taking care of them' (Cheshire et al., 2009: 243) than deleting their data at the end of the project. Finally, researcher confidentiality may need to be protected as qualitative researchers may reveal (and report) personal information as part of rapport building.

\section{Revisits and restudies}

Given that archiving of qualitative data collected in developing countries is relatively rare, revisits or restudies by the original or a different researcher are still the main ways of engaging with earlier research and serve a dual purpose of confirming the original findings (Breman et al., 1997) and investigating the long-term outcomes for research participants (and sometimes, also the effects of research on research participants; see Article 1 by Crow in this issue). There are numerous examples of revisits and, to a lesser extent, restudies of qualitative research sites in developing countries, for example, the ESRC recently funded a team to restudy Indian villages studied in the 1950s by F.G. Bailey, Adrian C. Mayer

Progress in Development Studies 13, 4 (2013) pp. 323-338 
and David Pocock at the instigation of one of the original researchers. ${ }^{8}$ Other examples are: Breman (2007, Gujarat, India); Breman et al. (1997, South and South East Asia); Freeman (1983, Samoa); Lewis (1951, Mexico); and Van Schendel (1981, Bangladesh). Kloos (1997) attributes this enthusiasm to improved transport networks which make it easy for researchers to return to where they first did research, combined with a growth in the number of scholars seeking research sites and a growing interest in longitudinal studies. Some restudies have provoked considerable controversy in the media as well as academia, for example, the restudy by Freeman (1983) of the Samoan location studied by Margaret Mead (1928); or by Oscar Lewis (1951) of Tepoztlán, famously studied in the 1920 s by Robert Redfield (1930) (Table 2). ${ }^{9}$ The reason for the controversy may relate to interpretive overreach on the part of the original researcher - arguably, if Mead had not used her findings to critique adolescence in North America, or Redfield to launch modernization studies, then they would have received little media attention.

Restudies can occur within a single project, for example, when qualitative researchers visit areas where survey enumerators have or are working, or as a result of inevitable changes within or of research teams. The long-term engagement of ethnographers can be seen as a programme of 'rolling' revisits where each visit is in conversation with previous ones, for example, Geertz's (1995) 40 years of fieldwork in Pare in Indonesia. Our interest is in what Burawoy (2003: 650) calls a 'focused revisit' (restudy) which he defines as 'an intensive comparison of one's own field work with a prior ethnography of the same site, usually conducted by someone else'. An example from his own work is his return to the Geer Company factory, Illinois, in 1979, which was studied by Roy in 1944-45. Given the time difference, and that initially he did not realize that he was revisiting Roy's research site, Burawoy's main purpose was not replication. However, he perceived some differences between his and Roy's findings which could not be entirely explained by the passage of time (see also the debate between Redfield and Lewis, Table 2). Burawoy explains these differences from constructivist (changes in knowledge of the object) and realist perspectives (changes in the object of knowledge), recognizing both the role of the authors' different theoretical orientations and the substantial external changes that had taken place (for example, the absorption of the factory into a monopoly sector). The distinction between constructivist and realist perspectives is also important for reanalysis - a contemporary development researcher might be more likely to use James Scott than Rosa Luxembourg or Samuel Popkin to analyze peasant rebellion and his/her analysis would be shaped by the increasing penetration of neoliberalism and capitalism.

Burawoy (2003) distinguishes four different types of focused revisit, which he loosely categorizes as constructivist or realist (see preceding paragraph), recognizing that in the examples he uses, these categories often overlap. Constructivist revisits (types 1 and 2) assume that the site being studied at two points in time does not change, but rather it is the different relation of the ethnographer to the site (type I) (for example, Burawoy's positionality as an English student researcher compared to Roy's North American blue-collar worker in their study of the Geer Company factory) or the different theory that the ethnographer brings to the site (type 2) (for example, Weiner's [1976] feminist reconstruction of Malinowski's (1922) Argonauts of the Western Pacific, which highlighted the importance of mortuary ceremonies in cementing women's control over ancestral identity alongside Malinowski's celebration of the 'Kula ring'). Realist revisits (types 3 and 4) are designed specifically to study historical change. Type 3 revisits give primary attention to internal processes (for example, Caplow et al.'s [1982] revisit of Lynd and Lynd's [1929] study of 'Middletown', Indiana), while type 4

Progress in Development Studies 13, 4 (2013) pp. 323-338 
revisits give more weight to external forces in accounting for differences between authors depictions (for example, Hutchinson's [1996] revisit to Nuerland [now southern Sudan], which was studied by Evans-Pritchard [1940], explicitly to explore the impact of decolonization, war, Christianity and transnational capital on the lives of the Nuer). Burawoy (2003: 647) emphasizes that replication and revisits are fundamentally different: 'the purpose of the revisit is the exact opposite: to focus on the inescapable dilemmas of participating in the world we study, on the necessity of bringing theory to the field, all with a view to developing explanations of historical change'. However, his typology acknowledges that replication could be one reason for a revisit. For example, Tierney's (2000) attempted refutation of the conclusions of Chagnon's (1968) Yanomamö: The Fierce People, which became the subject of an investigation by the American Anthropological Association due to his accusations that Chagnon misrepresented the Yanomamö as inherently violent and started a measles epidemic (Borofsky, 2004).

The idea that replication is an important but not the sole reason for a revisit is echoed by Davies and Charles (2002: 1.1) who claim that while revisits are 'a deliberate intent to repeat insofar as possible a previous research study using the same research design and methods', this is in order to "better understand social change' rather than to critique the original research. Crow (2002: 4.3) suggests similarly that the strength of revisits (and by extension, reanalysis) lies not only in the potential they give us to be "critical both of what was said in the previous research and of what was overlooked', but also to 'ground the analysis... in a way that attempts to discover the interconnected nature of the various social forces at work'. The anthropological example that we give next, drawing on Burawoy (2003), shows how revisits can ground analyses and through this, situate and challenge the conclusions of the original researchers. It also provides a disturbing insight into the way that particular findings are taken up by policymakers without an understanding of their broader context.

In Land, Labour and Diet in Northern Rhodesia, Richards (1939) predicted the 'breakdown' of Bemba society when its men migrated to the mines of southern Africa because the slash-and-burn agricultural system (citimene) could not survive without men to cut down the trees. However, when Moore and Vaughan (1994) returned to northern Zambia (previously Northern Rhodesia) in the 1980s, they found that the citimene system was thriving. Moore and Vaughan (1994) suggested that Richards had underestimated the resourcefulness and adaptive capacities of Bemba women who engaged in their own forms of cultivation and were able to use the produce from this to persuade men to continue felling trees. Richards' conclusions inadvertently reproduced concerns among Bemba chiefs and colonial administrators relating to the durability and desirability of citimene, which was used to evade taxation and tribal obligations, and so contributed to its repression:

As a particular account of Bemba history [Land, Labour and Diet] also became part of that history. The conventional wisdom Richards (1939) propagated - that Bemba society was in a state of 'breakdown' was deployed by colonial and postcolonial administrations to justify their attempts to transform Bemba agriculture. (Burawoy, 2003: 666)

Moore and Vaughan (1994) argue that Bemba livelihoods and well-being were damaged not by citimene, but by the Zambian government's agrarian reforms in the 1980s, which assumed that citimene was moribund. These reforms encouraged male workers to return from the Zambian Copperbelt and begin cultivating maize, which required women to provide large inputs of labour at the expense of subsistence agriculture and domestic tasks, including care for infants. While this is a powerful illustration of the inherent dangers of the research/policy relationship, Burawoy

Progress in Development Studies 13, 4 (2013) pp. 323-338 
(2003: 667) suggests that Moore and Vaughan may have committed a similar error in failing to situate themselves within their own work: 'their own analysis might have been one-sided, governed by specific feminist and Foucauldian assumptions, and thereby contributed to discourses that would shape the Bemba world of future revisits... In restoring Richards to history, ironically Moore and Vaughan placed themselves outside history'.

Maintaining an historical perspective through longitudinal research, including revisits, presents challenges when, as Burawoy (2003: 675) puts it, so many parts of the world [are] dissolving, reconfiguring, and recomposing under the pressure of their global connections and, at the same time, other parts stagnating because of their global disconnections' (see also Geertz, 1995: 2). Referring to his own work, Burawoy (2003: 674) describes how in order to revisit Geer Company (now Allied Corporation), he would need to 'study the homeless recyclers that now, hypothetically, inhabit the vacant lot that used to be Allied... Or I could go off to South Korea where, again hypothetically, Allied's new engine division can be found'. Nonetheless, there are examples of revisits where new researchers were able to reconstruct and build on the work of their predecessors, albeit mostly from economically developed societies such as the UK, and the best known are summarized in Table 2 . In addition to these examples, Harriss-White and Harriss (2007), Harriss et al. (2010), Scarlett Epstein (1973), M.N. Srinivas (2012), Biplab Dasgupta (1978), and Jan Breman (2007) have conducted multiple revisits to sites in rural India where there is a strong tradition of 'village studies'. This programme of research has enabled comprehensive accounts of communities and households over time, which was previously the preserve of lone anthropologists rather than interdisciplinary teams. Breman, for example, has made a detailed analysis of the effects of global capitalism on the poorest workers in India over the past 50 years, drawing on evidence from sociology, anthropology, economics and history, and repeated revisits to the same sites in south Gujarat. ${ }^{10}$

\section{Conclusion}

In this review, we have looked at the potential of revisits and reanalysis to provide both new insights into the original and related topics and a means of confirming the quality of data production and interpretation. While this process is not without problems - see especially Table 3 - it offers development researchers an opportunity to build on and critically appraise the work of others in their own and related fields, for example, by testing whether the insights of a seminal study in a particular context are equally applicable somewhere else. It can only happen, however, if researchers have the time and inclination to record their activities and share detailed and uncensored methodological accounts alongside their data.

Within some disciplines, this would be a realistic expectation, given that the raw material for archiving is broadly that which a reflexive ethnographic study should provide." However, reluctance to archive qualitative data and accompanying research materials relates not only to the time and skills required to create research materials of sufficient quality, but also to reluctance to expose the messy, contradictory nature of social science research (Silva, 2007). These concerns may be exacerbated by the professionalization of social science and the career strategies of social scientists, which Cheshire et al. (2009: 249) describe as increasingly tied to 'positivist or empiricist criteria that value impacts, outputs and policyrelevance over critical or theoretical engagement' (see also Mauthner and Edwards, 2010). In this context, the requirement to archive data can be seen as a further erosion of academic freedom in the face of increasing demands to make research socially useful, albeit this demand is not a novelty in applied fields such as international development (Hammersley and Traianou, 2012: chapter 1; Moore, 2007). Finally, there may be a perception that the

Progress in Development Studies 13, 4 (2013) pp. 323-338 
satisfaction of clients such as DFID, reflected in offers of funding or new commissions, provides sufficient evidence of research quality. We would argue that this is not the case and that researchers in development have much to learn from each other, from their shared history and from work in other disciplines.

\section{Notes}

1. Special issues include Sociological Research Online 12(3); International Journal of Social Research Methodology 7(1) and 15(4); Forum: Qualitative Social Research 1(3) and 6(1); and Australian Journal of Social Issues 44(3).

2. The ESRC have had a Datasets Policy since 1996, which requires projects not only to archive but also to demonstrate that there is no archived data they could have used before collecting new data (see www.esrc. ac.uk/_images/Research_Data_Policy_2010_tcm84595.pdf). The failure to archive data on the part of development researchers prompted one of the main recommendations of a recent Department for International Development (DFID) report on poverty research, which related to the availability of highquality data, specifically longitudinal qualitative and quantitative datasets (Poverty Analysis Discussion Group [PADG], 2012).

3. See www.data-archive.ac.uk/find/internationalarchives for archives in Europe and North America, some of which contain qualitative as well as quantitative data, and www.esds.ac.uk/qualidata/ access/internationaldata.asp for social science archives with substantial qualitative components.

4. In the field, not understanding the language of the interview can lead to other insights, for example, observing while a research assistant interviews an informant, or interviewing the research assistant to capture their impressions.

5. Hammersley (2010) gives the example of the anthropologist Frederik Barth's struggles to use the fieldnotes of a colleague who had died, which illustrates the challenges in using others' fieldnotes due to their personal and idiosyncratic nature, even when the user is a contemporary and friend working on a similar topic.

6. This is a familiar insight for survey researchers (Tourangeau et al., 2000), but given that questions are used more flexibly in qualitative research and comparisons between cases are made in less mechanistic ways, it has probably not received the attention it deserves among qualitative researchers.

7. Louise Corti, the Associate Director of the UK Data Archive, argues that these problems can be dealt with through licensing, which controls access to and the use of datasets (personal communication, January 2011).

8. Adrian Mayer; see http://www.soas.ac.uk/ anthropology/rural-change-and-anthropologicalknowledge-in-post-colonial-india/

9. While Freeman's revisit is better known, in the 1950s, Mead was revisited by Holmes in one of the first attempts to systematically verify an anthropologist's work. Mead also conducted her own revisit to see how the context and her response to it had changed over the intervening 30 years. Redfield was active in his own revisit as he commented extensively on discrepancies between his account and Lewis's and attempted to explain them in relation to Lewis's political commitments.

10. In a speech given on the award of an honorary doctorate to Breman, Jan Pronk describes how 'villagers, noting that [Breman] was asking the same questions as decades earlier, sometimes thought that he, or the boss who had sent him, was a bit stupid, because he had been made to repeat the same question. But that is, and should be, the attitude of a student of development: society changes, but the questions are the same: who did benefit, who lost?' (www.janpronk.nl/speeches/english/laudatio-dr-janbreman.html, last accessed in October 2012).

11. Examples can be seen in archived classic anthropological and sociological studies such as Malinowski, Mead, Caplan and the Pioneers of Qualitative Research (www.esds.ac.uk/qualidata/ pioneers/). See also Irwin and Winterton (2011: appendix A), for a list of materials to accompany archived data, which includes material relating to analysis and presentation.

\section{References}

Alymov, S. 2011: On the Soviet ethnography of the Soviet life: The case of the village of Viriatino. Histories of Anthropology Annual 7, 23-48.

Bishop, L. 2007: A reflexive account of reusing qualitative data: Beyond primary/secondary dualism. Sociological Research Online 12, http://www.socresonline.org. uk/12/3/2.html, last accessed on 30 May 2013. 2009: Ethical sharing and reuse of qualitative data. Australian Journal of Social Issues 44, 255-72.

Blaxter, M. and Patterson, E. 1982: Mothers and daughters: A three-generational study of health attitudes and behaviour. Heinemann Educational Books.

Bornat, J. 2005: Recycling the evidence: Different approaches to the reanalysis of gerontological data. Forum: Qualitative Social Research, 6.

Borofsky, R. 2004: Yanomami: The fierce controversy and what we can learn from it (illustrated edition). University of California Press.

Bott, E. 1957: Family and social network. Free Press.

Progress in Development Studies 13, 4 (2013) pp. 323-338 
Breman, J.P. 1985: Of peasants, migrants and workers, rural labour circulation and capitalist production in west. Clarendon Press.

2007: The poverty regime in village India. Oxford University Press.

Breman, J.P., Kloos, P. and Saith, A., editors. 1997: The village in Asia revisited. Oxford University Press.

British Sociological Association 2002: Statement of ethical practice for the British Sociological Association, http://www.britsoc.co.uk/ media/27107/StatementofEthicalPractice.pdf, last accessed on 30 May 2013.

Broom, A., Chesire, L. and Emmison, M. 2009: Qualitative researchers' understandings of their practice and the implications for data archiving and sharing. Sociology 43, 1163-80.

Bryson, L. and Winter, I. 1972: An Australian newtown: Life and leadership in a new housing suburb. Penguin 1999: Social change, suburban lives. Allen and Unwin.

Burawoy, M. 2003: Revisits: An outline of a theory of reflexive ethnography. American Sociological Review $68,645-79$.

Camfield, L. 2014: Introduction. In Research in international development: A critical review. Palgrave Macmillan, forthcoming.

Caplow, T., Chadwick, B.A., Bahr, H.M. and Hill, R. 1982: Middletown families: Fifty years of change and continuity. University of Minnesota Press.

Chagnon, Napoleon A. 1968: Yanomamö: The fierce people.

_ 1968: Yanomamö: The fierce people. Holt, Rinehart and Winston.

Charles, N., Aull Davies, C. and Harris, C. 2008: The family and social change revisited. In Edwards, R., editor, Researching families and communities: Social and generational change. Routledge, 114-32.

Cheshire, L., Broom, A. and Emmison, M. 2009: Archiving qualitative data in Australia: An introduction. Australian Journal of Social Issues 44, 239-54.

Cohen, S. and Taylor, L. 1972: Psychological survival. Penguin.

Crow, G. 2002: Community studies: Fifty years of theorization. Sociological Research Online 7, http:// www.socresonline.org.uk/7/3/crow.html, last accessed on 30 May 2013.

Crow, G. and Edwards, R. 2012: Perspectives on working with archived textual and visual material in social research: Editors' introduction. International Journal of Social Research Methodology $15,259-62$

Dasgupta, B., editor. 1978: Village studies in the third world. Hindustan Publishing Company.

Davies, C.A. and Charles, N. 2002: The piano in the parlour: Methodological issues in the conduct of a restudy. Sociological Research Online, 7, http://www. socresonline.org.uk/7/2/davies.html, last accessed on 30 May 2013.

Dennis, F., Henriques, F. and Slaughter, C. 1956: Coal is our Life. An analysis of a Yorkshire mining community. Tavistock.

Descola, P. 2005: On anthropological knowledge. Social Anthropology 13, 65-73.

Epstein, S. 1973: South India: Yesterday, today, and tomorrow: Mysore villages revisited. Holmes and Meier.

Evans-Pritchard, E.E. 1940: The Nuer: A description of the modes of livelihood and political institutions of a Nilotic people. Oxford University Press.

Fielding, N.G. and Fielding, J.L. 2000: Resistance and adaptation to criminal identity: Using secondary analysis to evaluate classic studies of crime and deviance. Sociology 34, 671-89.

Freeman, D. 1983: Margaret Mead and Samoa: The making and unmaking of an anthropological myth. Cambridge University Press.

Geertz, C. 1995: After the fact: Two countries, four decades, one anthropologist. Harvard University Press.

Geiger, T., Moore, N. and Savage, M. 2010: The archive in question. ESRC National Centre for Research Methods Review Paper NCRM/016.

Gillies, V. and Edwards, R. 2005: Secondary analysis in exploring family and social change: Addressing the issue of context. Forum: Qualitative Social Research 6, http://www.qualitative-research.net/index.php/ fqs/article/view/500/1076, last accessed on 30 May 2013.

2011: An historical comparative analysis of family and parenting: A feasibility study across sources and timeframes. Families and Social Capital Research Group, Working Paper No. 24.

Goldthorpe, J., Lockwood, D., Bechhofer, F. and Platt, J. 1968: The affluent worker: Industrial attitudes and behaviour. Cambridge University Press.

Hammersley, M. 1997: Qualitative data archiving: Some reflections on its prospects and problems. Sociology 31, 131-42.

2009: Against the ethicists: On the evils of ethical regulation. International Journal of Social Research Methodology 12, 211-25.

___ 2010: Can we re-use qualitative data via secondary analysis? Notes on some terminological and substantive issues. Sociological Research Online 15, http://www.socresonline.org.uk/15/1/5.html, last accessed on 30 May 2013.

Hammersley, M. and Traianou, A. 2012: Ethics in qualitative research controversies and contexts. SAGE.

Harriss, J., Jeyaranjan, J. and Nagaraj, K. 2010: Land, labour and caste politics in rural Tamil Nadu in the 20th century: Iruvelpattu (1916-2008). Economic and Political Weekly 45, 47-61. 
Harriss-White, B. and Harriss, J. 2007: Green revolution and after: The 'North Arcot papers' and long-term studies of the political economy of rural development in south India. QEH Working Paper No. 146.

Hutchinson, S. 1996: Nuer dilemmas: Coping with money, war, and the state. University of California Press.

Irwin, S. and Winterton, M. 2011: Debates in qualitative secondary analysis: Critical reflections. Timescapes Working Paper.

2012: Qualitative secondary analysis: A guide to practice. Timescapes Methods Guides Series No. 19.

Johnson, J., Rolph, S. and Smith, R. 2010: Residential care transformed: Revisiting 'The last refuge'. Palgrave.

Kloos, P. 1997: Restudies in anthropology: Modalities, limitation and alternatives. In Breman, J., Kloos, P. and Saith, A., editors, The village in Asia revisited. Oxford University Press.

Kushner, P., editor. 1958: The village of Viriatino (trans. S. Benet, 1970). Doubleday

Lewis, O. 1951: Life in a Mexican village urbana. University of Illinois Press.

Lewis, D. 2009: International development and the 'perpetual present': Anthropological approaches to the re-historicization of policy. European Journal of Development Research 21, 32-46.

Lincoln, Y. and Guba, E. 1985: Naturalistic inquiry. SAGE.

Lynd, Robert S. and Lynd, Helen M. 1929: Middletown: A study in contemporary American culture. Harcourt, Brace, and Company.

Lynd, R. and Lynd, H. 1937: Middletown in transition: A study in cultural conflicts. Harcourt, Brace and Company.

Malinowski, B. 1922: Argonauts of the western Pacific. Routledge.

Marsden, D. 1969: Mothers alone: Poverty and the fatherless family. Allen Lane.

Mason, J. 2007: 'Re-using' qualitative data: On the merits of an investigative epistemology. Sociological Research Online 12, http://www.socresonline.org. uk/12/3/3.html, last accessed on 30 May 2013.

Mauthner, N.S. and Doucet, A. 2008: 'Knowledge once divided can be hard to put together again': An epistemological critique of collaborative and teambased research practices. Sociology 42, 971-85.

Mauthner, N.S. and Edwards, R. 2010: Possibilities and practices of feminist research management in higher education in Britain. Gender, Work and Organisation 17, 481-502.

Mauthner, N.S. and Parry, O. 2009: Qualitative data preservation and sharing in the social sciences: On whose philosophical terms? Australian Journal of Social Issues 44, 289-305.
Mauthner, N.S., Parry, O. and Backett-Milburn, K. 1998: The data are out there, or are they? Implications for archiving and revisiting qualitative data. Sociology 324, 733-45.

Mead, M. 1928: Coming of age in Samoa: A psychological study of primitive youth for western civilisation. William Morrow.

Moore, N. 2006: The contexts of context: Broadening perspectives in the re-use of qualitative data. Methodological Innovations Online 12, http://www. esds.ac.uk/news/publications/MIOMoore-pp21-32. pdf, last accessed on 30 May 2013.

2007: Re:using qualitative data. Sociological Research Online 12, http://www.socresonline.org. uk/12/3/1.html, last accessed on 30 May 2013.

Moore, H. and Vaughan, M. 1994: Cutting down trees: Gender, nutrition, and agricultural change in the northern province of Zambia, 1890-1990. Heinemann.

O'Connor, H. and Goodwin, J. 2010: Utilizing data from a lost sociological project: Experiences, insights, promises. Qualitative Research 10, 283-98.

Parry, O. and Mauthner, N.S. 2004: Whose data are they anyway? Practical, legal and ethical issues in archiving qualitative research data. Sociology 38, 139-52.

Phillipson, C., Bernard, M., Phillips, J. and Ogg, J. 1998: The family and community life of older people: Household composition and social networks in three urban areas. Ageing and Society 18, 259-89.

Poverty Analysis Discussion Group (PADG) 2012: Understanding poverty and wellbeing: A note with implications for research and policy. DFID Research and Evidence Division.

Redfield, R. 1930: Tepoztlán: A Mexican village. University of Chicago Press.

Richards, A. 1939: Land, labour and diet in Northern Rhodesia: An economic study of the Bemba tribe. Oxford University Press.

Rosser, C. and Harris, C.C. 1965: The family and social change. Routledge and Kegan Paul.

Savage, M. 2005a: Revisiting classic qualitative studies. Forum: Qualitative Social Research 61, http://www. qualitative-research.net/index.php/fqs/article/ view/502/1081, last accessed on 30 May 2013.

2005b: Working class identities in the 1960s: Revisiting the affluent worker study. Sociology 39, 929-46.

___ 2007: Changing social class identities in post-war Britain: Perspectives from massobservation. Sociological Research Online 123, http:// www.socresonline.org.uk/12/3/6.html, last accessed on 30 May 2013.

Savage, M. 2008: Elizabeth Bott and the formation of modern British sociology. The Sociological Review 54, 579-605. 
Sheldon, J.H. 1948: The social medicine of old age: Report of an inquiry in Wolverhampton. Oxford University Press.

Silva, E.B. 2007: What's [yet] to be seen? Re-using qualitative data. Sociological Research Online 12, www.socresonline.org.uk/12/3/4.html, last accessed on 30 May 2013.

Srinivas, M.N. 2012: The remembered village. Oxford University Press.

Stanley, L. 1990: Moments of writing: Is there a feminist auto/biography? Gender and History 2, 58-67.

Temple, B., Edwards, R. and Alexander, C. 2006: Grasping at context: Cross language qualitative research as secondary qualitative data analysis. Forum: Qualitative Social Research 74, http://nbnresolving.de/urn:nbn:de:0114-fqs0604107, last accessed on 30 May 2013.

Thompson, P. 1975: The Edwardians: The remaking of British society. Routledge.

Tierney, P. 2000: Darkness in El Dorado: How scientists and journalists devastated the Amazon. W.W. Norton.

Tourangeau, R., Rips, L.J. and Rasinski, K. 2000: The psychology of survey response. Cambridge University Press.
Townsend, P. 1962: The last refuge: A survey of residential institutions and homes for the aged in England and Wales. Routledge and Kegan Paul.

Travers, M.H. 2009: A not so strange silence: Why qualitative researchers should respond critically to the qualitative data archive. Australian Journal of Social Issues 44, 273-89.

Van den Eynden, V., Corti, L., Woollard, M., Bishop, L. and Horton, L. 2011: Managing and sharing data; Best practice for researchers. UK Data Archive, University of Essex.

Van Schendel, W. 1981: Peasant mobility: The odds of life in rural Bangladesh. Van Gorcum.

Walters, P. 2009: Qualitative archiving: Engaging with epistemological misgivings. Australian Journal of Social Issues 44, 309-20.

Warwick, D. and Littlejohn, G. 1992: Coal, capital and culture: A sociological analysis of mining communities in west Yorkshire. Routledge.

Weiner, A. 1976: Women of value, men of renown. University of Texas Press.

Young, M. and Willmott, P. 1957: Family and kinship in East London. Routledge. 